\title{
RECENZE
}

\section{Eduard DROBERJAR - Balázs KOMORÓCZY (eds.), ŘíMSKÉ A GERMÁNSKÉ SPONY VE STŘEDNÍ EVROPĔ (Archeologie barbarů 2012), Spisy Archeologického ústavu AV ČR Brno, sv. 53, Brno 2017.}

\section{Zdeněk Beneš}

Takzvané Protohistorické konference, známé rovněž pod titulem „Archeologie barbarů“, jsou od roku 2005 jedinou specializovanou př́ležitostí k setkávání širší archeologické obce nad tématy doby římské a doby stěhování národů $\mathrm{s}$ těžištěm ve střední Evropě, včetně období, která s nimi chronologicky úzce souvisejí. Podobně jako u jiných, chronologicky zaměřených konferencí, rovněž na těchto setkáních mají př́ležitost potkat se ostřílení badatelé se studenty a začínajícími archeology, na rozdíl od velkých mezinárodních konferencí, na něž se jezdívá na pozvání. Tato „,barbarská“ setkání jsou katalyzátorem postupu výzkumu nad konkrétními tématy zájmových období, ale také místem utužování sociálních vztahů mezi badateli, které pomáhají jednotlivce motivovat do dalšího výzkumu. Jak mnozí z nás dobře vědí, na takový výzkum nebývá vždy prostor v pracovní době běžného archeologického zaměstnání, především v případě terénně vytížených archeologů.

Tématem VIII. Protohistorické konference, která se odehrála v prostorách Univerzity Palackého v Olomouci 2.5. října 2012, byly spony doby římské. Ač se jedná o jednu jedinou nálezovou kategorii, zasvěcení vědí, že spínadla hrají ve vědeckém zkoumání protohistorických období mezi artefakty prvořadou roli. Jsou nezastupitelná především při zkoumání otázek chronologie, ale významnou úlohu mají také pro řešení mezikulturních vztahů, migrací, obchodu mezi římskými provinciemi a barbarikem. Bez významu však nejsou ani při sledování postupu římské armády během bojových operací za hranicemi Rímské říše, nebo naopak při začleňování barbarských bojovníků do struktur římské armády. Je tomu ostatně letos právě 20 let, co v Německu vznikl velký sborník dokumentující stav výzkumu spon jedno rovné století od vydání disertační práce Oscara Almgrena, jenž položil základy systematiky třídění tohoto druhu šperku. ${ }^{1}$

Do aktuálně vydaného konferenčního sborníku si našly cestu především příspěvky autorů, kteří proslovili referáty na olomoucké konferenci. Jedná se o 33 př́spěvků od celkem 49 autorů. Cesta referátů od konání konference až $\mathrm{k}$ jejich

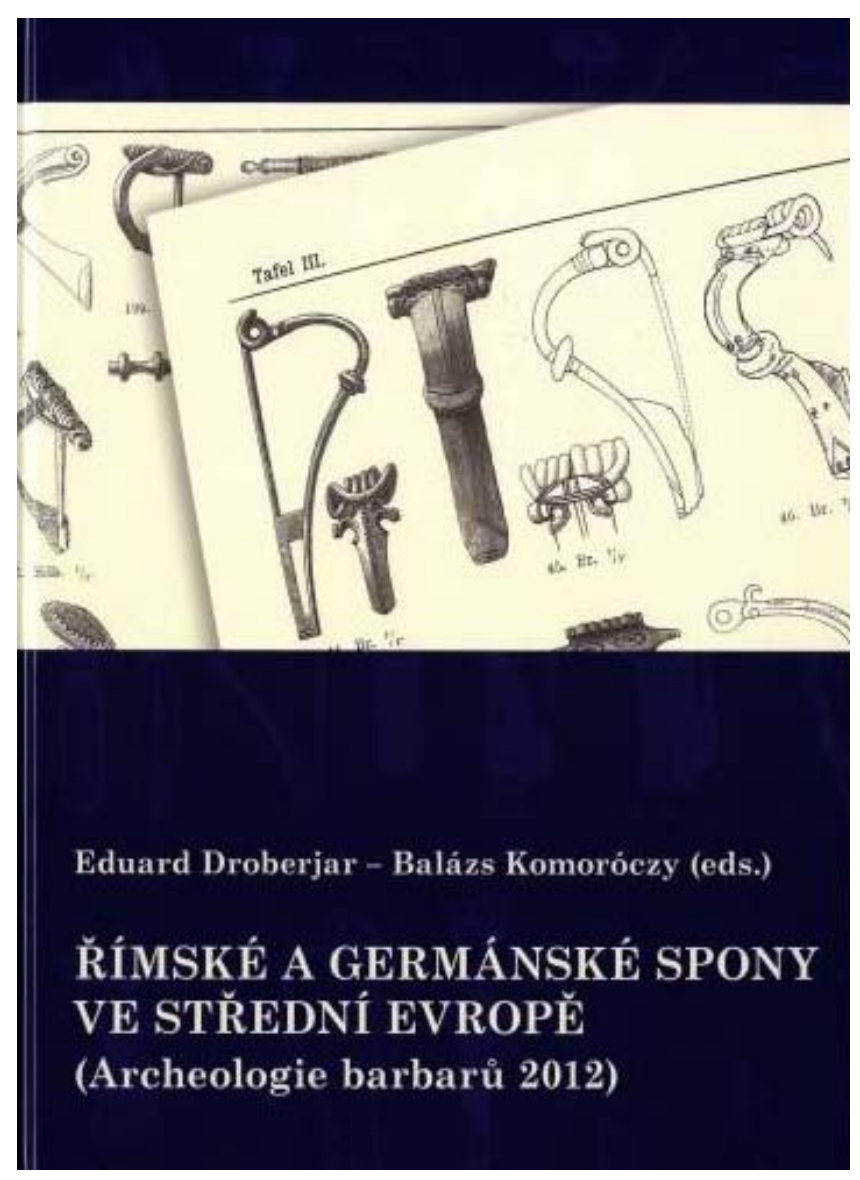

uveřejnění v předloženém sborníku byla dlouhá a klikatá trvala 5 let, než se jich po Univerzitě Olomouc ujal Archeologický ústav AV ČR v Brně a začlenil je (ostatně již potřetí) do své řady Spisy AÚ AV ČR. Některé z textů během této doby bohužel poněkud zastaraly. Přesto se však jedná o více než pětisetstránkové kompendium, které v našich končinách tematicky nemá konkurenci. Sborník je věnován památce

${ }^{1}$ Jürgen KUNOW (Hrsg.), 100 Jahre Fibelformen nach Oscar Almgren, Forschungen zur Archäologie im Land Brandenburg 5, Wünsdorf 1998. 
Tita Kolníka, velké osobnosti slovenské archeologie a předního specialisty na dobu římskou a stěhování národů na Slovensku.

První př́spěvek od E. Droberjara je metodického rázu a seznamuje čtenáře se základy klasifikace spon, správným popisem, dokumentací a také základní odbornou literaturou. Byt' rozsahem krátký, je tento článek první skutečnou specializovanou učební pomůckou pro zkoumání artefaktů doby římské, pomineme-li obecnější, nikoli tak podrobný přehled z pera K. Sklenáře a M. Lutovského. ${ }^{2}$ Droberjarův text je mimořádně vhodný především pro studenty archeologie, ale také pro kolegy, kteří se dosud sponami ve své praxi př́liš nezabývali. Pro zájemce je možné doporučit ještě objemnější německou př́ručku. ${ }^{3}$ Druhý metodický př́íspěvek od autorského týmu B. Komoróczyho, M. Vlacha a M. Zelíkové pak pojednává o dokumentaci a možnostech interpretační výpovědi jednoho jediného typu římské spony na území středního Podunají. Na tomto př́kladu je názorně vidět, $\mathrm{k}$ čemu je možné poznatky z postupně shromažd'ované databáze nálezů použít. Tento text také poprvé v tomto sborníku otevírá velké téma, kterým jsou kovové nálezy získané během prospekcí s detektory kovů (profesionálně i amatérsky vedených, legálních i nelegálních). ${ }^{4}$

Sborník je dále členěn do skupin článků podle hlediska chronologického a kulturního. Nejprve jsou to spony laténské (příspěvky G. Brežňanové, R. Čambala, M. Karwowského a článek kolektivu polských autorů A. Michałowského, M. Tesky a D. Żychlińského) a dále spony provinciálně-ř́mské (H. Sedlmayer, M. Mérczi, I. Bazovský, K. Elschek, A. Námerová a dvojice autorů M. Olędzki a L. Ziąbka). Jmenované př́spěvky se většinou zabývají konkrétním typem spony na daném území a jeho historicko-kulturními souvislostmi. Vyzdvihnout lze s ohledem na nálezy z našeho území např́klad příspěvek H. Sedlmayer o sponách typu Aucissa, které jsou obvykle spojovány s přítomností rímské augustovské armády. Autorka oproti tomu ukazuje jejich roli v oblasti severovýchodní Itálie, kde představují součást ženského kroje, pomalu se proměňujícího během procesu romanizace.

IV. kapitola sborníku pojednává o římských a germánských sponách společně, a to především z toho důvodu, že nálezové soubory, které jsou předmětem dotčených článků, není účelné uměle rozdělit podle kulturní př́íslušnosti. V této kapitole se rovněž nachází dvojice textů, které patří mezi první „vlaštovky“ výsledků spolupráce mezi profesionálními archeology a amatérskými hledači s detektory kovů. Obě studie jsou víceméně regionálně zaměřené. První, od kolektivu autorů E. Droberjar, J. John a P. Zavřel, pojednává o sponách z jižních Čech (v čele s lokalitou Sedlec), respektive shrnutí dokladů starších nálezů významně doplněných o nálezy nové. $\mathrm{Na}$ tomto prríkladě je názorně vidět, jak dramaticky se mění nálezové spektrum v momentě, kdy je do něj zapojeno větší množství nálezů, které by se jinde a za horších podmínek k archeologům nemusely dostat. Př́spěvek M. Ďugy, D. Vachůtové a T. Zemana se zabývá sponami nalezenými na místě jediného sídliště v Hrubé Vrbce na jihovýchodní Moravě. Lokalita objevená amatérským archeologem se stala těžištěm projektu archeologů profesionálních, kteří zde prováděli povrchové prospekce i sondáže. Ohromující množství kovových nálezů pak pochopitelně ovlivňuje i celkový náhled na kulturní vývoj osídlení v podhưří Bílých Karpat, považovaného za okrajovou sídelní oblast. Zbývá doplnit, že v době zcela nedávné byla publikována monografie T. Zemana o výsledcích (nejen) detektorových prospekcí v regionu středního Pomoraví a je tak první monograficky zaměřenou prací na tuto problematiku v ČR. ${ }^{5}$ Je nepochybné, že pokud se podaří něco podobného provést $\mathrm{i} v$ dalších regionech, kde spolupráce profesionálních archeologů s amatéry probíhá na dobré úrovni, posune se naše chápání vývoje osídlení a jeho kulturních proměn o notný kus dopředu.

Kapitola V. se věnuje textům zaobírajícím se výlučně germánskými sponami doby římské, respektive doplněním poznatků k některým jejich typům. Pozornost je upřena především na střední Podunají v době markomanských válek (R. Ivan) či v pozdní době rímské (V. Varsik). Ve dvou příspěvcích se zase obracíme do Polska k problematice spon s podvázanou nožkou (př́spěvky J. Andrzejowského a M. Olędzkého s J. Ziętkem). Oblasti Čech se dotýká příspěvek jediný, paradoxně polské autorky A. Reszczyńské. Sponám z doby stěhování národů je věnována VI. kapitola, která sestává z pouhých dvou texti̊. V nich se čtenár podívá do exotických krajů ruského Pobaltí (K. N. Skvorcov a M. Rudnicki) nebo vizigótského Španělska (J. Pinar Gil).

Již tradičně je poslední kapitola sborníků Archeologie barbarů věnována také „Variím“, tj. textům, které zcela neodpovídají hlavnímu tématu konference. Vyzdvihnout je třeba především obsáhlý přehled nálezů a lokalit $\mathrm{z}$ doby římské a stěhování národů v oblasti severní Moravy (okres Šumperk) z pera J. Halamy. Autor zde ukazuje, jak odlišný je v této podhorské oblasti vývoj osídlení vůči úrodným nížinám. Především je patrné, že většina nálezů spadá do širšího období kolem markomanských válek (probíhaly v letech 166-181 n. 1., pozn. autora). Je namístě uvažovat, zda posun osídlení i do méně úrodných oblastí nějak s těmito událostmi nesouvisí, at' již jako prŕíčna, či důsledek. Ostatně, od naposledy objeveného nejsevernějšího tábora římské armády v Jevíčku na Svitavsku již podhůří Jeseníků zdaleka nepředstavuje nedosažitelný bod. Na tomto místě však nebudeme tak dalece spekulovat. Varia doplňují články o nově objevených laténských výšinných lokalitách v Novém Městě nad Metují (T. Bek, T. Mangel a D. Vích), analýza domněle autentického souboru římských spon z lokality Sandberk u Kolína (Z. Beneš), publikace zajímavého kostrového hrobu ze 4. století z východních Čech (J. Jílek, J. Kopřivová a P. Hornik) a kriminální zápletka týkající se zlatého závěsku z nedávno zkoumaného ,langobardského“ pohřebiště v Hostivici u Prahy (D. Daněček, R. Korený a D. Perlík).

Zde recenzovaný sborník Archeologie barbarů navazuje na již v minulosti $\mathrm{v}$ různých vědeckých řadách zveřejněné

\footnotetext{
${ }^{2}$ Karel SKLENÁ ̌̌ - Michal LUTOVSKÝ, Archeologický slovník. Část 2., Kovové artefakty. 1. Pravěk a raný středověk, Praha 1992.

${ }^{3}$ Ronald HEYNOWSKI, Fibeln. Erkennen - bestimmen - beschreiben, Bestimmungsbuch Archäologie 1, München 2012 (2. rozšířené vydání 2016).

${ }^{4}$ Téma již dříve tematizováno v Eduard DROBERJAR, K významu detektorových nálezů pro zkoumání doby římské, Živá archeologie - REA, 2015/17, 69-72.

${ }^{5}$ Tomáš ZEMAN, Střední Pomoraví v době římské. Svědectví povrchové prospekce, Archaeologica Olomucensia II, Olomouc 2017.
} 
příspěvky z Protohistorických konferencí. Vzhledem k délce přípravy této knihy ji v publikaci ,předběhly“ některé následující ročníky. Př́íspěvky z Protohistorické konference z roku 2013 v Bratislavě našly prostor v periodiku Študijné zvesti Archeologického ústavu SAV, resp. v jeho číslech 61/2017, 62/2017 a 63/2018. Př́íspěvky z konference z roku 2014 v polské Wieluni pak byly publikovány opět v samostatném sborníku. ${ }^{6}$ Publikace dalších ročníků je v současné chvíli $\mathrm{v}$ běhu. Je třeba poznamenat, že od ročníku 2017 bylo z různých důvodů přistoupeno na obroční stř́íání konference „malí barbaři““ a „velcí barbaři“, kdy pouze ta druhá, několikadenní, bude mít publikační východisko.

${ }^{6}$ Lubomira TYSZLER - Eduard DROBERJAR (red.), Archeologia barbarzyńców 2014. Barbari superiores et inferiores, Łódź - Wieluń 2015. 